\title{
Intranasal Insulin: a Treatment Strategy for Addiction
}

\author{
Bhavani Kashyap ${ }^{1,2}$ (D) $\cdot$ Leah R. Hanson ${ }^{1,2}$. William H. Frey II ${ }^{1,2}$
}

Published online: 2 January 2020

(C) The American Society for Experimental NeuroTherapeutics, Inc. 2020

\begin{abstract}
Addiction to substances such as alcohol, cocaine, opioids, and methamphetamine poses a continuing clinical and public challenge globally. Despite progress in understanding substance use disorders, challenges remain in their treatment. Some of these challenges include limited ability of therapeutics to reach the brain (blood-brain barrier), adverse systemic side effects of current medications, and importantly key aspects of addiction not addressed by currently available treatments (such as cognitive impairment). Inability to sustain abstinence or seek treatment due to cognitive deficits such as poor decision-making and impulsivity is known to cause poor treatment outcomes. In this review, we provide an evidenced-based rationale for intranasal drug delivery as a viable and safe treatment modality to bypass the blood-brain barrier and target insulin to the brain to improve the treatment of addiction. Intranasal insulin with improvement of brain cell energy and glucose metabolism, stress hormone reduction, and improved monoamine transmission may be an ideal approach for treating multiple domains of addiction including memory and impulsivity. This may provide additional benefits to enhance current treatment approaches.
\end{abstract}

Key words Nose-to-brain delivery $\cdot$ hypometabolism $\cdot$ alcohol use disorder $\cdot$ cortisol

\section{Introduction}

Addiction to substances such as alcohol, cocaine, opioids, and methamphetamine poses a continuing clinical and public challenge globally. In the United States, $25 \%$ of adults report binge alcohol consumption, and 7\% (nearly 17 million) are diagnosed with alcohol use disorders [1]. Although the reported numbers are smaller for other substance use, they result in increased healthcare costs, utilization, and adverse health outcomes [1]. In the last 15-20 years, there is a better understanding of the pathological changes within the brain and its circuitry that promote substance abuse. However, challenges remain in the treatment of drug addiction that can potentially be addressed by novel approaches such as intranasal drug delivery, specifically intranasal insulin as discussed here.

Bhavani Kashyap

Bhavani.X.Kashyap@HealthPartners.Com

1 HealthPartners Neuroscience Center, 295 Phalen Blvd, St Paul, Minnesota 55130, USA

2 HealthPartners Institute, Bloomington, Minnesota, USA
Currently, pharmacotherapy exists only for alcohol use disorders (AUD) and opioid addiction, but has several limitations including multiple adverse effects, compliance with dosing regimen, availability/access, and utilization of treatment [2-12]. A comprehensive review of the current treatment for drug addiction is beyond the scope of this review. Briefly, focus of treatment is largely dependent on managing withdrawal symptoms, psychotherapy, and support groups. Pharmacotherapy for AUD (FDA approved) includes disulfuram, naltrexone, nalmefene, and acamprosate and a few non-FDA-approved treatments such as topiramate, baclofen, or gabapentin $[2,3]$. Despite extensive research, there are currently no effective pharmacological based treatments for other addictive substances, including psychoactive stimulants (cocaine, methamphetamines), marijuana or synthetic cannabinoids, hallucinogens, phencyclidine (PCP), or drugs such as methylenedioxymethamphetamine (MDMA) [13, 14].

Limitations to pharmacotherapy include treatment under supervision, aversive reaction (disulfiram), precipitation of opioid withdrawal in opioid users (naltrexone), dosing regimen compliance (acamprosate), specialized treatment (topiramate), and multiple side effects, with some serious outcomes. Opioid addiction is commonly treated with methadone and buprenorphine [2]. Methadone is associated with multiple adverse outcomes including constipation, respiratory depression, and heart rhythm abnormalities, whereas buprenorphine 
can precipitate opioid withdrawal [2]. Another important limitation for an effective treatment is the blood-brain barrier (BBB). The BBB severely limits the therapeutics that can be used and use of high doses to overcome the BBB can lead to systemic side effects.

Multiple aspects of both acute and long-term management are neither targeted nor addressed by currently available pharmacological and non-pharmacological therapies [10]. Recent articles suggest that across all substance use disorders (SUD), cognitive deficits exist that are known to predict treatment response and sustained abstinence [14-18]. Most commonly encountered cognitive deficits include impaired or poor decision-making ability, impulsivity, impaired cognitive flexibility, deficits in learning and memory, and heightened attention to drug-associated cues $[14,15]$. In addition, both addicts in abstinence with cognitive deficits and people with mood disorders are at higher risk of substance use or relapse [16-18]. This suggests that for a favorable outcome of treatment or prevention of relapse or maintenance of abstinence, it is essential to treat cognitive and behavioral deficits. We present the rationale for using intranasal insulin, which has the potential to treat multiple targets within the brain including cognitive deficits and to address key limitations and challenges currently faced in the treatment of addiction.

\section{Intranasal Drug Delivery}

In 1989, William Frey II filed the first patent on his discovery of the intranasal delivery method, which bypasses the BBB to target therapeutics (including insulin) to the brain to treat brain disorders including Alzheimer's disease and stroke [19-22]. Subsequently, William Frey II received an additional patent on the specific use of intranasal insulin to treat Alzheimer's disease and Parkinson's disease [23, 24].

Since its discovery, intranasal delivery of drugs to the central nervous system (CNS) has been successfully demonstrated by numerous researchers worldwide, resulting in many publications. Intranasal delivery has been studied extensively with regard to mechanism of transport to the brain. Intranasal therapeutics reach the CNS within minutes via extracellular mechanisms including perineural and perivascular transport [22, 25-34]. Intranasal drug delivery to the brain is dependent on extracellular convection or bulk flow along the olfactory and trigeminal neural pathways whereas delivery throughout the brain involves passage through the perivascular spaces of the cerebrovascular system on the brain side of the BBB [35]. Intranasal insulin can be found in the cerebrospinal fluid in humans $10 \mathrm{~min}$ after administration [27]. It is not essential that drugs be modified for intranasal drug delivery to the CNS. Key advantages of intranasal delivery include allowing for direct delivery of large and/or charged therapeutics to the CNS from the nasal mucosa while reducing systemic exposure and adverse side effects for multiple brain therapeutics including those that cross the BBB. In addition to peptides [36, 37], such as insulin, charged small molecules [38], adenoassociated virus gene therapy [39], therapeutic cells including stem cells [40, 41], T cells [42], macrophages, and microglia [43] have all been delivered to the brain to treat CNS disorders. Multiple intranasal therapeutics for treating brain disorders have been developed [44-56], but this review focuses on restoring brain cell energy and metabolism, and other actions of intranasal insulin that can potentially be beneficial for the treatment of addiction.

\section{Intranasal Insulin}

The use of intranasal insulin administration to non-invasively deliver and target insulin to the brain could lead to advancements in treatment for addiction. The intranasal insulin treatment has been shown in multiple human clinical trials to safely improve memory, attention, and functioning in patients with mild cognitive impairment (MCI) or Alzheimer's disease (AD), to improve memory, motor symptoms in patients with Parkinson (PD), to improve memory in adults with type 2 diabetes, and even to improve memory in normal healthy adults [57-70]. In addition, intranasal insulin has been studied with regard to food/eating behavior, diabetes (insulin resistance), stress axis, and sleep [71-79].

Study of the pharmacokinetics of intranasal insulin in mice showed only $3 \%$ of intranasal insulin entered the circulation and no peripheral metabolic effects were detected up to a day after intranasal administration [80]. A single intranasal dose of $40 \mathrm{IU}$ insulin induces an increase in the cerebrospinal fluid concentration of insulin distinctly above the normal level in healthy individuals [27]. A recent review of safety of intranasal human insulin trials revealed no safety concerns, with no serious adverse events or symptomatic hypoglycemia in a total of 1092 individuals studied [81]. Though some studies with higher doses (160 IU) have shown small detectable increase in insulin levels, no significant change in blood glucose levels were noted [82].

\section{Insulin and Substance Use Disorders}

Multiple reviews by Koob and colleagues over the years have provided extensive evidence for involvement of multiple neurotransmitter systems and brain areas involved in development, and evolution of different phases of the addiction cycle [83-89]. Different classes of drugs are associated with dysfunctions in a range of overlapping brain regions including midbrain dopamine pathways (ventral tegmental area [VTA], substantia nigra [SN]), basal ganglia (ventral striatum, nucleus accumbens [NAcc], and dorsal striatum) prefrontal cortex ([PFC]; dorsolateral prefrontal cortex [DLPFC], ventromedial prefrontal cortex [vmPFC]), cingulate cortex, hippocampus, 
inferior frontal gyrus, insula, amygdala, and cerebellum involved in drug reward, emotion, cognition, and behavior.

Insulin signaling has been determined to be instrumental in the overall health and function of the central nervous system (CNS) $[59,90]$. Studies have demonstrated that insulin and insulin receptors (IR) are expressed widely within the brain as in peripheral tissues [91, 92]. Insulin levels in the brain when compared to plasma can reach 10 to 100 times higher, especially in hippocampus, hypothalamus, cortex, olfactory bulb, substantia nigra, and pituitary $[92,93]$. Briefly, insulin binds to the insulin receptor (IR) resulting in the phosphorylation of insulin receptor substrate (IRS) resulting in activation of two signaling pathways (phosphatidylinositol 3-kinase [PI3K]$\mathrm{AKT} /$ protein kinase $\mathrm{B}[\mathrm{PKB}]$ and Ras-mitogen-activated protein kinase [MAPK] pathways) known to play pivotal roles in normal brain function. Beginning from insulin levels in the periphery to specific molecular and cellular targets within the brain, impairments occur and span across different stages of the addiction cycle. Specifically relevant to this review, we discuss the current evidence for impaired insulin signaling in SUD.

\section{Reward and Habit Formation}

The mesolimbic dopamine system (VTA, striatum) is generally considered the most important mediator of drug reward and appears to be common to both acute and chronic effects of SUD [83].

\section{Dopamine Neurotransmission}

Dopamine transporter (DAT), an enzyme associated with clearing of extracellular DA, is a major target of substance use (cocaine, amphetamine) associated with stimulant actions. Insulin has been shown to increase DAT expression, suggesting a key role in mediating the cognitive and motivational effects [94-100]. Pre-clinical studies in animals and tissue cultures suggest that persistent DAT function at DA nerve terminals in striatum are due to activation of IRs, through stimulation of the PI3K pathway [96, 97, 101]. In addition, insulin modulates the pre-synaptic transporters sensitive to cocaine in nucleus accumbens (NAcc) suggesting a target for treatment of impulsivity in these patients [102]. In humans, Akt has been found to be associated with MA abuse and associated dysregulation of the DA system [103, 104]. Moreover, the insulin functions mentioned above suggest a potential relationship between addiction and food intake processes associated with DA neurotransmission and its pathway [98, 105-107]. Application of insulin at the VTA reduces food intake and consumption of high fat food, presumably affecting the DA neurocircuitry [108-110].

Currently, multiple studies have targeted these mechanisms using intranasal insulin in studying eating or food-related behaviors. Intranasal insulin has been shown to reduce food intake in adult men [111] and snacks in women if given in a suitable time window [73]. Tiedemann and colleagues [78] used intranasal insulin to demonstrate the link between feeding systems, and modulation of mesolimbic pathways by insulin with regard to food stimuli in humans. Thanarajah and colleagues in 2019 [60] report the pharmacokinetics of intranasal insulin and dose dependency of its modulatory effects on the midbrain. Key findings of this study suggest that insulin regulates feeding behavior through its action on midbrain dopamine neurons and the ensuing consequences for rewardrelated and motivational processes [110, 112]. With similar mechanisms between SUD and impaired feeding systems, a recent study shows the promise of intranasal insulin for SUD. Briefly, Naef et al. studied the effects of intranasal insulin along with intra-VTA insulin in rats and showed that DA in NAc was suppressed by insulin and blocked by an insulin receptor antagonist suggesting suppression of attention to drug related cues with cocaine [113].

\section{Insulin Signaling}

Apart from DA in the VTA, insulin is thought to act on multiple targets through its downstream effects of signaling in the CNS. For example, in long-term opioid (morphine) users, decreased levels of insulin growth factor-1 (IGF-1) and insulin receptor substrate (IRS) proteins have been demonstrated in the VTA $[114,115]$. Studies in Drosophila of mutations of insulin-like peptides showed that insulin signaling is involved with toxic effects of alcohol by potentially engaging insulin signal transduction mechanisms [116]. Similarly, the disruption of the phosphatidylinositol-3 kinase (PI3K) cascade in the VTA by a dominant negative insulin receptor substrate 2 (IRS2) protein attenuates the rewarding properties of cocaine and morphine in rodents $[117,118]$. Animal studies with repeated administration of methamphetamine also showed effects on insulin signaling due to impaired expression of multiple components of insulin signaling such as IRs, PI3K and glycogen synthase kinase 3-beta (GSK3 $\beta$ ) [119, 120]. Overall, the studies mentioned above suggest the potential use of intranasal insulin to address impaired insulin signaling in the brain.

\section{Other Neurotransmitters}

Along with DA, multiple neurotransmitters are involved in mediating the drug reward effects in SUDs. Independent neurotransmission involving the opioid peptides, GABA, and endocannabinoids are known to affect the mesolimbic system $[84,88]$. Insulin is also known to modulate the effect of a number of these neurotransmitters such as GABA by activating synaptic IR and may reduce symptoms in depression and sleep regulation [121-125]. In addition, insulin induced long- 
term depression (LTD) of AMPA-mediated excitatory postsynaptic transmission by synthesis of endocannabinoids, and glutamate release onto VTA dopamine neurons $[126,127]$. Although this shows the potential of insulin affecting these systems, further studies are required to establish the interplay with insulin signaling, especially in the midbrain.

\section{Cognition and Behavior}

Neurocognitive impairments are common to all SUD [128, 129 ]. Cocaine, methamphetamine, 3,4methylenedioxymethamphetamine (MDMA), and nicotine are associated with neurocognitive changes including learning and working memory deficits with acute or chronic exposure, present during abstinence [130-137] and associated with poor treatment outcomes. It is hypothesized that pre-existing working memory deficits increase vulnerability to drug addiction [14]. In AUD, deficits are observed in executive functioning (such as abstract reasoning, problem solving skills, and cognitive flexibility), visuospatial abilities, and perceptual-motor integration, and these deficits are persistent beyond several weeks of abstinence $(45 \%)$ or a year of abstinence (15\%; [138-141]). In the sections below, we discuss mechanisms known to be involved in SUD which may possibly be improved with intranasal insulin.

\section{Cerebral Hypometabolism}

Cerebral hypometabolism with reduced glucose uptake and related neuro-structural changes are key factors involved in acute and long-term cognitive impairment or deficits in individuals with SUD, including AUD. Preclinical studies in animals undergoing withdrawal after chronic extended access to cocaine showed decreased glucose utilization of brain regions involved in learning and memory such as the PFC, hippocampus, and striatum [142]. Significant reduction of glucose utilization in some of these regions lasts longer and may facilitate continued drug use even if associated with tolerance and negative effects. Moreover, consistent with human studies, animals with impaired memory showed significantly higher seeking behavior for drugs than do controls. For example, neonatal ventral hippocampal lesions in rats, which lead to working memory deficits, resulted in increased reinstatement of nicotine seeking [143]. In addition, chronic exposure to nicotine, methamphetamine, and cocaine, or cocaine withdrawal resulted in changes in neurogenesis in the hippocampus [144-148].

In 1966, Roach and colleagues provide the initial suggestion that impaired glucose metabolism may be an underlying cause for alcoholism [149]. Decades later, brain imaging studies have shown reduced glucose utilization by the brain, in both resting and sensory stimulation during acute alcohol administration, including with low doses of alcohol in humans ((with or without behavioral abnormalities) [89, 150-158]).
Studies using ${ }^{18} \mathrm{~F}$-2-fluoro-deoxy-glucose (FDG)-positron emission topography (PET) in patients with AUD show that there is $20 \%$ global reduction in glucose uptake [159], similar to results in neurologically intact patients with AUD [152, 155]. In addition, regional changes in hypometabolism were observed in the frontal cortex including the anterior cingulate cortex (ACC) when compared to controls [159-162]. Regional changes in hypometabolism have been suggested to be linked to cognitive dysfunction, as reduced frontal and anterior cingulate metabolism are reported to correlate with mental control, category subset scores [155, 161], fourdimensional neurocognitive model (verbal memory, visual memory, verbal knowledge, and attention/executive functioning, [163]) and Wisconsin Card Sorting Test scores in alcoholics respectively $[139,164]$. To further elucidate changes in glucose metabolism in AUD, Ritz et al. showed grey matter shrinkage and hypometabolism in the fronto-cerebellar circuit and several nodes of Papez's circuit, along with some regions showing disproportionate increase in hypometabolism when compared to grey matter shrinkage [165]. In addition, AUD with Korsakoff's syndrome results in cerebral glucose hypometabolism with particular severity in the middle cingulate cortex [166]. AUD is frequently associated with anxiety and depression. Clinical studies have shown altered posterior cingulate cortex functions in patients with mood disorders, including decreases in cerebral glucose metabolism [167, 168 ] and activation during emotional processing [169], relative to healthy controls.

Insulin and insulin signaling transduction play a key role in modulating cognition. Central insulin and IRs have been established as differing from that of the systemically occurring counter parts that specifically regulate glucose utilization. Energy metabolism in the CNS is largely dependent on glucose uptake and its utilization. Glucose metabolism is essential for both neuronal and non-neuronal physiological functions, regulation of cerebral blood flow, cell death pathways, and neurotransmitter synthesis [170]. Although there are multiple regulators of glucose metabolism in CNS [170], one of the key regulators is insulin, especially in certain brain regions.

In rodents, IRs and insulin-sensitive glucose transporters are selectively co-localized in brain areas responsible for memory, thus providing a platform for insulin signaling whereby selective increases in cerebral glucose utilization could modulate memory [171]. Consistent with evidence of insulin functioning as a neuromodulator for memory-related function is the high density of IRs in the hippocampus and cerebral cortex, brain regions integral to the formation, retention, and recall of information [90, 172]. Systems with impaired insulin signaling pathways have demonstrated inhibition of acetylcholine biosynthesis and subsequently have incurred debilitating effects on neuronal plasticity $[173,174]$. Increased insulin resistance and glucose intolerance has been 
observed in a multitude of neurodegenerative processes including Alzheimer's disease [175], Parkinson's disease [176], and Huntington's disease [177] suggesting a common pathway.

Intranasal insulin in animal studies using Alzheimer's and Parkinson's disease models has been shown to improve cognitive function [178] [179] [80]. Fluorodeoxyglucose (FDG)PET imaging studies have demonstrated a reduction in the loss of glucose uptake and utilization after intranasal insulin treatment in patients with $\mathrm{AD}$ or amnestic MCI in the bilateral frontal, right temporal, bilateral occipital, and right precuneus and cuneus regions of the brain [63]. Specifically, clinical trials with intranasal insulin (both short and long term) in memory-impaired subjects (AD, MCI) have shown improvement in declarative memory tasks [70], greater story recall, improved word list recall with sustained benefit (21 day treatment) [180], and improved delayed memory during a 4-month treatment trial [63]. Improvement of cognitive function including glucose uptake and metabolism suggests that intranasal insulin may provide an opportunity to target specific cognitive deficits that may improve long-term outcomes with SUD. In support are the recent studies with intranasal insulin showing improvement in cognitive impairments and craving associated with addiction in smokers [181-183].

\section{Stress and HPA Axis}

Stress is an important trigger of relapse, and the brain systems that respond to stressful stimuli are thought to be important in maintaining the addicted state. Animal studies suggest activation of the stress/aversion systems (hypothalamic-pituitary axis [HPA], corticotrophin releasing factor [CRF], and dynorphin) and impairment of anti-stress systems (neuropeptide $\mathrm{Y}$ ) are associated with chronic drug relapse $[83,85,88$, 184]. Insulin is a known actor in HPA axis regulation by binding to IR in hypothalamus, hippocampus, and amygdala [112, 185-189]. Studies in humans suggest central insulin causes reduction in morning HPA axis activity and effectively lowers psychological stress induced HPA axis response by reduction in the level of cortisol [69, 190, 191]. Moreover, the insulin HPA axis response may be related to regulation of the arcuate nucleus of the hypothalamus, including its effects on energy homeostasis [192-194].

Intranasal insulin has been shown to attenuate the HPA axis and reduce cortisol in adult men exposed to stress [190], which is significant as cortisol blocks glucose uptake into the hippocampus [195]. In addition, intranasal insulin has been discussed as a potential intervention to ameliorate posttraumatic stress disorder (PTSD) [47]. Collectively, these studies provide rationale for testing intranasal insulin as a viable therapeutic in extending drug abstinence or reducing episodes of drug relapse in SUD.

\section{Neurogenesis}

Hippocampus is a key brain region involved in learning and memory. Impairment of hippocampal neurogenesis has been associated with cognitive deficits in neurodegenerative disorders including AD [196, 197]. Multiple animal and clinical studies in addiction and other psychiatric disorders, such as depression and schizophrenia, suggest that altered hippocampal neurogenesis is a key contributor of these complex clinical disorders [198-200]. Similarly, it is thought that a persistent decrease in hippocampal neurogenesis may increase susceptibility to engage in and maintain drug-seeking behaviors [201]. Briefly, self-administration studies of drugs have shown that reduced hippocampal neurogenesis is associated with increased drug taking and drug-seeking behavior, whereas increasing neurogenesis by exercise or treatment with anti-depressants reduces drug-taking and drugseeking behaviors $[199,200]$. The insulin signaling cascade plays a key role within the hippocampus. Insulin, insulin-like growth factors, IRs, and downstream activation of PI3 kinase and GSK $3 \beta$ are key players in dendritic sprouting, neuronal stem cell activation, cell growth, repair, synaptic maintenance, and neuroprotection [173, 175, 202-204]. Specifically within the hippocampus, insulin facilitates neuronal plasticity by modulating long-term potentiation or long-term depression at synapses [205]. These effects are mediated by PI3 kinase by modulating expression of glutamate receptors including AMPA and NMDA [206]. Further studies are required to elucidate the role of insulin signaling in SUD within the hippocampus.

Preclinical and neuroimaging evidence suggest involvement of PFC and its circuitry in direct effects of drugs, craving, response to cues, inhibitory control, and rewardbased decision-making. Using multiple approaches including intranasal insulin, all the PFC regions have been shown to be sensitive to changes in response to insulin, suggesting that insulin signaling may play a role with regard to craving and response to cues in SUDs [75, 82, 207, 208]. This speculation arises from studies using intranasal insulin showing reduced food intake by a) decreased response of the PFC to food cues [208] and a decrease in orbitofrontal cortex resting state activity [75]; b) increasing brain cell energy (ATP and phosphocreatine) using phosphorus-31magnetic resonance imaging [209].

In summary, studies presented here suggest that insulin is a key modulator in all SUD and targets multiple mechanisms specifically energy metabolism, glucose uptake, neurotransmission, synaptic plasticity, and HPA axis regulation. This suggests that intranasal insulin could play a significant role in the treatment of addiction and associated cognitive deficits in SUD. 


\section{Future of Treatment in Addiction-Intranasal Insulin}

Intranasal insulin offers an exciting and viable approach to addressing some of the key aspects of SUD, including improving rates of treatment use due to its ease of use and safety. As described in the sections above, intranasal insulin treatment for cerebral glucose hypometabolism has been studied in multiple clinical trials, and benefits related to cognitive and memory impairments have been reported. In summary, intranasal insulin studies show that it 1) safely improves memory in normal healthy adults and in patients with mild cognitive impairment or Alzheimer's disease; 2) reduces cerebral glucose hypometabolism in patients with $\mathrm{AD} ; 3$ ) increases both brain cell energy, ATP, and phosphocreatine in normal healthy adults; 4) attenuates the HPA axis and cortisol response to psychosocial stress in healthy adults; and 5) can be safely tested in patients. The safety and efficacy of intranasal insulin to improve memory, executive functions, drug-seeking behaviors, and control impulsivity in individuals with SUD needs to be assessed in clinical trials.

According to the 2015 National Survey on Drug Use and Health (NSDUH), of the 20.8 million people aged 12 or older who had a SUD during the past year, about 2.7 million (13 percent) had both an alcohol use and an illicit drug use disorder, and 41.2 percent also had a mental illness. With this significant level of polysubstance use, it is important to focus on therapeutics such as intranasal insulin that may provide a practical strategy to improve the treatment of multiple SUD [210].

Required Author Forms Disclosure forms provided by the authors are available with the online version of this article.

\section{Compliance with Ethical Standards}

Conflict of Interest The authors declare that they have no conflict of interest. Although two authors LH and WF are listed inventors on patents related to intranasal Insulin, owned by their non-profit employer, none of these patents are related to the treatment of addiction.

\section{References}

1. Abuse S. Mental Health Services Administration (2018). Key substance use and mental health indicators in the United States: Results from the 2017 National Survey on Drug Use and Health (HHS Publication No. SMA 18-5068, NSDUH Series H-53). Rockville, MD: Center for Behavioral Health Statistics and Quality. Substance Abuse and Mental Health Services Administration Retrieved from https://www samhsa gov/data. 2018.

2. Klein JW. Pharmacotherapy for Substance Use Disorders. Med Clin N Am 2016;100(4):891-910.

3. Carvalho AF, Heilig M, Perez A, Probst C, Rehm J. Alcohol use disorders. Lancet (London, England). 2019;394(10200):781-92.
4. Kranzler HR, Soyka M. Diagnosis and Pharmacotherapy of Alcohol Use Disorder: A Review. Jama. 2018;320(8):815-24.

5. Swift RM, Aston ER. Pharmacotherapy for alcohol use disorder: current and emerging therapies. Harv Rev Psychiatry 2015;23(2):122.

6. Antonelli M, Ferrulli A, Sestito L, Vassallo GA, Tarli C, Mosoni $\mathrm{C}$, et al. Alcohol addiction - the safety of available approved treatment options. Expert Opin Drug Saf 2018;17(2):169-77.

7. Soyka M, Muller CA. Pharmacotherapy of alcoholism - an update on approved and off-label medications. Expert Opin Pharmacother 2017;18(12):1187-99.

8. Ayanga D, Shorter D, Kosten TR. Update on pharmacotherapy for treatment of opioid use disorder. Expert Opin Pharmacother 2016;17(17):2307-18.

9. Dematteis M, Auriacombe M, D'Agnone O, Somaini L, Szerman $\mathrm{N}$, Littlewood R, et al. Recommendations for buprenorphine and methadone therapy in opioid use disorder: a European consensus. Expert Opin Pharmacother 2017;18(18):1987-99.

10. Volkow ND, Jones EB, Einstein EB, Wargo EM. Prevention and Treatment of Opioid Misuse and Addiction: A Review. JAMA Psychiatry 2019;76(2):208-16.

11. Salsitz E, Wiegand T. Pharmacotherapy of Opioid Addiction: "Putting a Real Face on a False Demon". J Med Toxicol 2016;12(1):58-63.

12. Fields JB, Dabam III WF, Dfasam D, Wilford BB. Opioid Pharmacotherapies for Substance Use Disorders and Addiction. The American Society of Addiction Medicine Handbook on Pain and Addiction 2018:221.

13. Ballester J, Valentine G, Sofuoglu M. Pharmacological treatments for methamphetamine addiction: current status and future directions. Expert Rev Clin Pharmacol 2017;10(3):305-14.

14. D'Souza MS. Brain and Cognition for Addiction Medicine: From Prevention to Recovery Neural Substrates for Treatment of Psychostimulant-Induced Cognitive Deficits. Front Psychiatry 2019;10:509.

15. Stevens L, Verdejo-García A, Goudriaan AE, Roeyers H, Dom G, Vanderplasschen W. Impulsivity as a vulnerability factor for poor addiction treatment outcomes: a review of neurocognitive findings among individuals with substance use disorders. J Subst Abus Treat 2014;47(1):58-72.

16. Bell RP, Garavan H, Foxe JJ. Neural correlates of craving and impulsivity in abstinent former cocaine users: Towards biomarkers of relapse risk. Neuropharmacology. 2014;85:461-70.

17. D'Souza MS, Markou A. Neural substrates of psychostimulant withdrawal-induced anhedonia. Behav Neurosci Drug Addict: Springer; 2010. p. 119-78.

18. Domínguez-Salas S, Díaz-Batanero C, Lozano-Rojas OM, Verdejo-Garcia A. Impact of general cognition and executive function deficits on addiction treatment outcomes: Systematic review and discussion of neurocognitive pathways. Neurosci Biobehav Rev 2016;71:772-801.

19. Frey WH, II, inventor; Ramsey Foundation, St. Paul, Minn., assignee. Neurolic Agents for Nasal Administration to the Brain. PCT/US patent WO1991007947A1. 1991 13.06.1991.

20. Frey WH, II, inventor; Chiron Corporation, assignee. Method for Administering Neurologic Agents to the Brain. US patent 6,180, 603. 2001 Jan 302001.

21. Frey WH, II, inventor; Ramsey Foundation, St. Paul, Minn., assignee. Method of Administering Neurologic Agents to the Brain. US patent 5,624,898. 1997 Apr 29, 1997.

22. Crowe TP, Greenlee MHW, Kanthasamy AG, Hsu WH. Mechanism of intranasal drug delivery directly to the brain. Life Sci 2018;195:44-52.

23. Jogani V, Jinturkar K, Vyas T, Misra A. Recent patents review on intranasal administration for CNS drug delivery. Recent Pat Drug Deliv Formul 2008;2(1):25-40. 
24. Frey WH, II, inventor; Chiron Corporation, assignee. Method for Administering Insulin to the Brain. US patent 6,313,093 B1 2001 Nov 6, 2001.

25. Thorne RG, Emory CR, Ala TA, Frey WH, 2nd. Quantitative analysis of the olfactory pathway for drug delivery to the brain. Brain Res 1995;692(1-2):278-82.

26. Derad I, Willeke K, Pietrowsky R, Born J, Fehm HL. Intranasal angiotensin II directly influences central nervous regulation of blood pressure. Am J Hypertens 1998;11(8 Pt 1):971-7.

27. Born J, Lange T, Kern W, McGregor GP, Bickel U, Fehm HL. Sniffing neuropeptides: a transnasal approach to the human brain. Nat Neurosci 2002;5(6):514-6.

28. Thorne RG, Pronk GJ, Padmanabhan V, Frey WH, 2nd. Delivery of insulin-like growth factor-I to the rat brain and spinal cord along olfactory and trigeminal pathways following intranasal administration. Neuroscience. 2004;127(2):481-96.

29. Dhanda DS. Approaches for Drug Deposition in the Human Olfactory Epthelium. Drug Deliv Tech 2005.

30. Perras B, Marshall L, Kohler G, Born J, Fehm HL. Sleep and endocrine changes after intranasal administration of growth hormone-releasing hormone in young and aged humans. Psychoneuroendocrinology. 1999;24(7):743-57.

31. Garmise RJ, Staats HF, Hickey AJ. Novel dry powder preparations of whole inactivated influenza virus for nasal vaccination. AAPS PharmSciTech 2007;8(4):E81.

32. Kern W, Schiefer B, Schwarzenburg J, Stange EF, Born J, Fehm HL. Evidence for central nervous effects of corticotropin-releasing hormone on gastric acid secretion in humans. Neuroendocrinology. 1997;65(4):291-8.

33. Dhuria SV, Hanson LR, Frey WH, 2nd. Intranasal delivery to the central nervous system: mechanisms and experimental considerations. J Pharm Sci 2010;99(4):1654-73.

34. Lochhead JJ, Wolak DJ, Pizzo ME, Thorne RG. Rapid transport within cerebral perivascular spaces underlies widespread tracer distribution in the brain after intranasal administration. J Cereb Blood Flow Metab 2015;35(3):371-81.

35. Lochhead JJ, Thorne RG. Intranasal delivery of biologics to the central nervous system. Adv Drug Deliv Rev 2012;64(7):614-28.

36. Chen XQ, Fawcett JR, Rahman YE, Ala TA, Frey IW. Delivery of Nerve Growth Factor to the Brain via the Olfactory Pathway. J Alzheimers Dis 1998;1(1):35-44.

37. Wolf DA, Hanson LR, Aronovich EL, Nan Z, Low WC, Frey $\mathrm{WH}, 2 \mathrm{nd}$, et al. Lysosomal enzyme can bypass the blood-brain barrier and reach the CNS following intranasal administration. Mol Genet Metab 2012;106(1):131-4.

38. Hanson LR, Frey WH, 2nd. Intranasal delivery bypasses the blood-brain barrier to target therapeutic agents to the central nervous system and treat neurodegenerative disease. BMC Neurosci. 2008;9 Suppl 3:S5

39. Belur LR, Temme A, Podetz-Pedersen KM, Riedl M, Vulchanova L, Robinson N, et al. Intranasal Adeno-Associated Virus Mediated Gene Delivery and Expression of Human Iduronidase in the Central Nervous System: A Noninvasive and Effective Approach for Prevention of Neurologic Disease in Mucopolysaccharidosis Type I. Hum Gene Ther 2017;28(7):576-87.

40. Danielyan L, Schafer R, von Ameln-Mayerhofer A, Bernhard F, Verleysdonk S, Buadze M, et al. Therapeutic efficacy of intranasally delivered mesenchymal stem cells in a rat model of Parkinson disease. Rejuvenation Res 2011;14(1):3-16.

41. Danielyan L, Schafer R, von Ameln-Mayerhofer A, Buadze M, Geisler J, Klopfer T, et al. Intranasal delivery of cells to the brain. Eur J Cell Biol 2009;88(6):315-24.

42. Fransson M, Piras E, Burman J, Nilsson B, Essand M, Lu B, et al. $\mathrm{CAR} / \mathrm{FoxP} 3$-engineered $\mathrm{T}$ regulatory cells target the CNS and suppress EAE upon intranasal delivery. J Neuroinflammation 2012;9:112.
43. Danielyan L, Beer-Hammer S, Stolzing A, Schafer R, Siegel G, Fabian C, et al. Intranasal delivery of bone marrow-derived mesenchymal stem cells, macrophages, and microglia to the brain in mouse models of Alzheimer's and Parkinson's disease. Cell Transplant 2014;23 Suppl 1:S123-39.

44. Fine JM, Baillargeon AM, Renner DB, Hoerster NS, Tokarev J, Colton $\mathrm{S}$, et al. Intranasal deferoxamine improves performance in radial arm water maze, stabilizes HIF-1alpha, and phosphorylates GSK3beta in P301L tau transgenic mice. Exp Brain Res 2012;219(3):381-90.

45. Fine JM, Forsberg AC, Renner DB, Faltesek KA, Mohan KG, Wong JC, et al. Intranasally-administered deferoxamine mitigates toxicity of 6-OHDA in a rat model of Parkinsons disease. Brain Res 2014;1574:96-104.

46. Frey WH. Delivery of 125I-NGF to the Brain via the Olfactory Route. Drug Deliv 1997;4:87-92.

47. Frey WH, 2nd. Intranasal insulin to treat and protect against posttraumatic stress disorder. J Nerv Ment Dis 2013;201(7):638-9.

48. Frey WHI, Danielyan L. Intranasal Delivery of Stem Cells \& Genetically Engineered Cells to the Brain. Drug Deliv Tech. 2010;10(1):39.

49. Hanson L, Fine J, Renner D, Svitak A, Burns R, Nguyen T, et al. Intranasal delivery of deferoxamine reduces spatial memory loss in APP/PS1 mice. Drug Deliv Transl Res 2012:1-9.

50. Hanson LR, Fine JM, Hoekman JD, Nguyen TM, Burns RB, Martinez PM, et al. Intranasal delivery of growth differentiation factor 5 to the central nervous system. Drug delivery. 2012.

51. Hanson LR, Fine JM, Svitak AL, Faltesek KA. Intranasal administration of CNS therapeutics to awake mice. J Vis Exp 2013(74).

52. Hanson LR, Frey WH, 2nd. Strategies for intranasal delivery of therapeutics for the prevention and treatment of neuroAIDS. J NeuroImmune Pharmacol 2007;2(1):81-6.

53. Hanson LR, Hafez D, Svitak AL, Burns RB, Li X, Frey WH, 2nd, et al. Intranasal phosphoramidon increases beta-amyloid levels in wild-type and NEP/NEP2-deficient mice. J Mol Neurosci 2011;43(3):424-7.

54. Hanson LR, Martinez PM, Taheri S, Kamsheh L, Mignot E, Frey WHI. Intranasal Administration of Hypocretin 1 (Orexin A) Bypasses the Blood-Brain Barrier \& Targets the Brain: A New Strategy for the Treatment of Narcolepsy. Drug Deliv Tech. 2004;4(4):81-6.

55. Johnson NJ, Hanson LR, Frey WH. Trigeminal pathways deliver a low molecular weight drug from the nose to the brain and orofacial structures. Mol Pharm 2010;7(3):884-93.

56. Renner DB, Frey WH, 2nd, Hanson LR. Intranasal delivery of siRNA to the olfactory bulbs of mice via the olfactory nerve pathway. Neurosci Lett 2012;513(2):193-7.

57. Schmid V, Kullmann S, Gfrorer W, Hund V, Hallschmid M, Lipp HP, et al. Safety of intranasal human insulin: A review. Diabetes Obes Metab 2018;20(7):1563-77.

58. Novak P, Pimentel Maldonado DA, Novak V. Safety and preliminary efficacy of intranasal insulin for cognitive impairment in Parkinson disease and multiple system atrophy: A doubleblinded placebo-controlled pilot study. PLoS One 2019;14(4): e0214364.

59. Bedse G, Di Domenico F, Serviddio G, Cassano T. Aberrant insulin signaling in Alzheimer's disease: current knowledge. Front Neurosci 2015;9:204.

60. Edwin Thanarajah S, Iglesias S, Kuzmanovic B, Rigoux L, Stephan $\mathrm{KE}$, Bruning JC, et al. Modulation of midbrain neurocircuitry by intranasal insulin. Neuroimage. 2019;194:120-7.

61. Benedict C, Hallschmid M, Schultes B, Born J, Kern W. Intranasal insulin to improve memory function in humans. Neuroendocrinology. 2007;86(2):136-42.

62. Claxton A, Baker LD, Hanson A, Trittschuh EH, Cholerton B, Morgan A, et al. Long-acting intranasal insulin detemir improves 
cognition for adults with mild cognitive impairment or early-stage Alzheimer's disease dementia. J Alzheimers Dis 2015;44(3):897906.

63. Craft S, Baker LD, Montine TJ, Minoshima S, Watson GS, Claxton A, et al. Intranasal insulin therapy for Alzheimer disease and amnestic mild cognitive impairment: a pilot clinical trial. Arch Neurol 2012;69(1):29-38.

64. Freiherr J, Hallschmid M, Frey WH, 2nd, Brunner YF, Chapman $\mathrm{CD}$, Holscher $\mathrm{C}$, et al. Intranasal Insulin as a Treatment for Alzheimer's Disease: A Review of Basic Research and Clinical Evidence. CNS Drugs. 2013.

65. Lu J, Xu Z. Efficacy of Intranasal Insulin in Improving Cognition in Mild Cognitive Impairment and Alzheimer Disease A systematic Review and Meta-Analysis. Am J Ther 2019.

66. Shemesh E, Rudich A, Harman-Boehm I, Cukierman-Yaffe T. Effect of intranasal insulin on cognitive function: a systematic review. J Clin Endocrinol Metab 2012;97(2):366-76.

67. Yu Q, Dai CL, Zhang Y, Chen Y, Wu Z, Iqbal K, et al. Intranasal Insulin Increases Synaptic Protein Expression and Prevents Anesthesia-Induced Cognitive Deficits Through mTOR-eEF2 Pathway. J Alzheimers Dis 2019;70(3):925-36.

68. Rosenbloom MH, Barclay TR, Pyle M, Owens BL, Cagan AB, Anderson CP, et al. A single-dose pilot trial of intranasal rapidacting insulin in apolipoprotein E4 carriers with mild-moderate Alzheimer's disease. CNS Drugs 2014;28(12):1185-9.

69. Benedict C, Hallschmid M, Hatke A, Schultes B, Fehm HL, Born $\mathrm{J}$, et al. Intranasal insulin improves memory in humans. Psychoneuroendocrinology. 2004;29(10):1326-34.

70. Reger MA, Watson GS, Frey WH, 2nd, Baker LD, Cholerton B, Keeling ML, et al. Effects of intranasal insulin on cognition in memory-impaired older adults: modulation by APOE genotype. Neurobiol Aging 2006;27(3):451-8.

71. Santiago JC, Hallschmid M. Outcomes and clinical implications of intranasal insulin administration to the central nervous system. Exp Neurol 2019.

72. Hallschmid M, Benedict C, Schultes B, Fehm HL, Born J, Kern W. Intranasal insulin reduces body fat in men but not in women. Diabetes. 2004;53(11):3024-9.

73. Hallschmid M, Higgs S, Thienel M, Ott V, Lehnert H. Postprandial administration of intranasal insulin intensifies satiety and reduces intake of palatable snacks in women. Diabetes. 2012;61(4):782-9

74. Guthoff M, Grichisch Y, Canova C, Tschritter O, Veit R, Hallschmid M, et al. Insulin modulates food-related activity in the central nervous system. J Clin Endocrinol Metab 2010;95(2):748-55.

75. Kullmann S, Frank S, Heni M, Ketterer C, Veit R, Haring HU, et al. Intranasal insulin modulates intrinsic reward and prefrontal circuitry of the human brain in lean women. Neuroendocrinology. 2013;97(2):176-82.

76. Kullmann S, Heni M, Veit R, Scheffler K, Machann J, Haring HU, et al. Selective insulin resistance in homeostatic and cognitive control brain areas in overweight and obese adults. Diabetes Care 2015;38(6):1044-50.

77. Schilling TM, Ferreira de Sa DS, Westerhausen R, Strelzyk F, Larra MF, Hallschmid M, et al. Intranasal insulin increases regional cerebral blood flow in the insular cortex in men independently of cortisol manipulation. Hum Brain Mapp 2014;35(5):1944-56.

78. Tiedemann LJ, Schmid SM, Hettel J, Giesen K, Francke P, Buchel $\mathrm{C}$, et al. Central insulin modulates food valuation via mesolimbic pathways. Nat Commun 2017;8:16052.

79. Santiago JC, Hallschmid M. Central Nervous Insulin Administration before Nocturnal Sleep Decreases Breakfast Intake in Healthy Young and Elderly Subjects. Front Neurosci 2017;11:54.
80. Salameh TS, Bullock KM, Hujoel IA, Niehoff ML, WoldenHanson T, Kim J, et al. Central nervous system delivery of intranasal insulin: mechanisms of uptake and effects on cognition. $\mathrm{J}$ Alzheimers Dis 2015;47(3):715-28.

81. Schmid V, Kullmann S, Gfrörer W, Hund V, Hallschmid M, Lipp HP, et al. Safety of intranasal human insulin: A review. Diabetes Obes Metab. 2018.

82. Kullmann S, Veit R, Peter A, Pohmann R, Scheffler K, Haring $\mathrm{HU}$, et al. Dose-Dependent Effects of Intranasal Insulin on Resting-State Brain Activity. J Clin Endocrinol Metab 2018;103(1):253-62.

83. Koob GF. The neurobiology of addiction: a neuroadaptational view relevant for diagnosis. Addiction. 2006;101:23-30.

84. Koob GF. Neurobiology of addiction. Focus. 2011;9(1):55-65.

85. Koob GF, Le Moal M. Drug addiction, dysregulation of reward, and allostasis. Neuropsychopharmacology 2001;24(2):97-129.

86. Koob GF, Le Moal M. Plasticity of reward neurocircuitry and the'dark side' of drug addiction. Nat Neurosci 2005;8(11):1442.

87. Koob GF, Sanna PP, Bloom FE. Neuroscience of addiction. Neuron. 1998;21(3):467-76.

88. Koob GF, Volkow ND. Neurobiology of addiction: a neurocircuitry analysis. Lancet Psychiatry 2016;3(8):760-73.

89. Volkow ND, Koob GF, McLellan AT. Neurobiologic advances from the brain disease model of addiction. $N$ Engl $J$ Med 2016;374(4):363-71.

90. Zhao WQ, Alkon DL. Role of insulin and insulin receptor in learning and memory. Mol Cell Endocrinol 2001;177(1-2):125-34.

91. Schulingkamp R, Pagano T, Hung D, Raffa R. Insulin receptors and insulin action in the brain: review and clinical implications. Neurosci Biobehav Rev 2000;24(8):855-72.

92. van der Heide LP, Ramakers GM, Smidt MP. Insulin signaling in the central nervous system: learning to survive. Prog Neurobiol 2006;79(4):205-21.

93. Frölich L, Blum-Degen D, Bernstein H-G, Engelsberger S, Humrich J, Laufer S, et al. Brain insulin and insulin receptors in aging and sporadic Alzheimer's disease. J Neural Transm 1998;105(4-5):423-38.

94. Patterson TA, Brot MD, Zavosh A, Schenk JO, Szot P, Figlewicz DP. Food deprivation decreases mRNA and activity of the rat dopamine transporter. Neuroendocrinology. 1998;68(1):11-20.

95. Owens WA, Sevak RJ, Galici R, Chang X, Javors MA, Galli A, et al. Deficits in dopamine clearance and locomotion in hypoinsulinemic rats unmask novel modulation of dopamine transporters by amphetamine. J Neurochem 2005;94(5):1402-10.

96. Williams JM, Owens WA, Turner GH, Saunders C, Dipace C, Blakely RD, et al. Hypoinsulinemia regulates amphetamineinduced reverse transport of dopamine. PLoS Biol 2007;5(10):e274.

97. Lute BJ, Khoshbouei H, Saunders C, Sen N, Lin RZ, Javitch JA, et al. PI3K signaling supports amphetamine-induced dopamine efflux. Biochem Biophys Res Commun 2008;372(4):656-61.

98. Figlewicz DP, Benoit SC. Insulin, leptin, and food reward: update 2008. Am J Phys Regul Integr Comp Phys 2009;296(1):R9-R19.

99. Giros B, Jaber M, Jones SR, Wightman RM, Caron MG. Hyperlocomotion and indifference to cocaine and amphetamine in mice lacking the dopamine transporter. Nature. 1996;379(6566):606.

100. Rothman RB, Baumann MH. Monoamine transporters and psychostimulant drugs. Eur J Pharmacol 2003;479(1-3):23-40.

101. Khoshbouei H, Sen N, Guptaroy B, Johnson LA, Lund D, Gnegy ME, et al. N-terminal phosphorylation of the dopamine transporter is required for amphetamine-induced efflux. PLoS Biol 2004;2(3):e78.

102. Schoffelmeer ANM, Drukarch B, De Vries TJ, Hogenboom F, Schetters D, Pattij T. Insulin Modulates Cocaine-Sensitive Monoamine Transporter Function and Impulsive Behavior. J Neurosci 2011;31(4):1284-91. 
103. Ikeda M, Iwata N, Suzuki T, Kitajima T, Yamanouchi Y, Kinoshiya Y, et al. Positive association of AKT1 haplotype to Japanese methamphetamine use disorder. Int $\mathrm{J}$ Neuropsychopharmacol 2006;9(1):77-81.

104. Emamian ES, Hall D, Birnbaum MJ, Karayiorgou M, Gogos JA. Convergent evidence for impaired AKT1-GSK3beta signaling in schizophrenia. Nat Genet 2004;36(2):131-7.

105. Palmiter RD. Is dopamine a physiologically relevant mediator of feeding behavior? Trends Neurosci 2007;30(8):375-81.

106. Figlewicz DP, Sipols AJ. Energy regulatory signals and food reward. Pharmacol Biochem Behav 2010;97(1):15-24.

107. Figlewicz DP, Naleid AM, Sipols AJ. Modulation of food reward by adiposity signals. Physiol Behav 2007;91(5):473-8.

108. Mebel DM, Wong JCY, Dong YJ, Borgland SL. Insulin in the ventral tegmental area reduces hedonic feeding and suppresses dopamine concentration via increased reuptake. Eur J Neurosci 2012;36(3):2336-46

109. Bruijnzeel AW, Corrie LW, Rogers JA, Yamada H. Effects of insulin and leptin in the ventral tegmental area and arcuate hypothalamic nucleus on food intake and brain reward function in female rats. Behav Brain Res 2011;219(2):254-64.

110. Kenny PJ. Common cellular and molecular mechanisms in obesity and drug addiction. Nat Rev Neurosci 2011;12(11):638-51.

111. Benedict C, Kern W, Schultes B, Born J, Hallschmid M. Differential sensitivity of men and women to anorexigenic and memory-improving effects of intranasal insulin. J Clin Endocrinol Metab 2008;93(4):1339-44.

112. Davis SN, Colburn C, Dobbins R, Nadeau S, Neal D, Williams P, et al. Evidence that the brain of the conscious dog is insulin sensitive. J Clin Invest 1995;95(2):593-602.

113. Naef L, Seabrook L, Hsiao J, Li C, Borgland SL. Insulin in the ventral tegmental area reduces cocaine-evoked dopamine in the nucleus accumbens in vivo. Eur J Neurosci 2019;50(3):2146-55.

114. Beitner-Johnson D, Nestler EJ. Chronic morphine impairs axoplasmic transport in the rat mesolimbic dopamine system. Neuroreport. 1993;5(1):57-60.

115. Wolf DH, Numan S, Nestler EJ, Russell DS. Regulation of phospholipase $\mathrm{C} \gamma$ in the mesolimbic dopamine system by chronic morphine administration. J Neurochem 1999;73(4):1520-8.

116. Corl AB, Rodan AR, Heberlein U. Insulin signaling in the nervous system regulates ethanol intoxication in Drosophila melanogaster. Nat Neurosci 2005;8(1):18-9.

117. Iniguez SD, Warren BL, Neve RL, Nestler EJ, Russo SJ, BolanosGuzman CA. Insulin receptor substrate-2 in the ventral tegmental area regulates behavioral responses to cocaine. Behav Neurosci 2008;122(5):1172-7.

118. Russo SJ, Bolanos CA, Theobald DE, DeCarolis NA, Renthal W, Kumar A, et al. IRS2-Akt pathway in midbrain dopamine neurons regulates behavioral and cellular responses to opiates. Nat Neurosci 2007;10(1):93-9.

119. Beirami E, Oryan S, Tamijani SMS, Ahmadiani A, Dargahi L. Intranasal insulin treatment alleviates methamphetamine induced anxiety-like behavior and neuroinflammation. Neurosci Lett 2017;660:122-9.

120. Beirami E, Oryan S, Seyedhosseini Tamijani SM, Ahmadiani A, Dargahi L. Intranasal insulin treatment restores cognitive deficits and insulin signaling impairment induced by repeated methamphetamine exposure. J Cell Biochem 2018;119(2):2345-55.

121. Jin Z, Jin Y, Kumar-Mendu S, Degerman E, Groop L, Birnir B. Insulin reduces neuronal excitability by turning on $\mathrm{GABA}(\mathrm{A})$ channels that generate tonic current. PLoS One 2011;6(1):e16188.

122. Duarte AI, Santos MS, Seiça R, Oliveira CRd. Insulin affects synaptosomal GABA and glutamate transport under oxidative stress conditions. Brain Res 2003;977(1):23-30.

123. Mielke JG, Wang YT. Insulin exerts neuroprotection by counteracting the decrease in cell-surface GABAA receptors following oxygen-glucose deprivation in cultured cortical neurons. J Neurochem 2005;92(1):103-13.

124. Wan Q, Xiong ZG, Man HY, Ackerley CA, Braunton J, Lu WY, et al. Recruitment of functional GABA(A) receptors to postsynaptic domains by insulin. Nature. 1997;388(6643):686-90.

125. Trujeque-Ramos S, Castillo-Rolón D, Galarraga E, Tapia D, Arenas-López G, Mihailescu S, et al. Insulin Regulates GABAA Receptor-Mediated Tonic Currents in the Prefrontal Cortex. Front Neurosci. 2018;12(345).

126. Labouèbe G, Liu S, Dias C, Zou H, Wong JCY, Karunakaran S, et al. Insulin induces long-term depression of ventral tegmental area dopamine neurons via endocannabinoids. Nat Neurosci 2013;16(3):300-8.

127. Kim SJ, Han Y. Insulin inhibits AMPA-induced neuronal damage via stimulation of protein kinase B (Akt). J Neural Transm 2005;112(2):179-91.

128. Fernandez-Serrano MJ, Perez-Garcia M, Verdejo-Garcia A. What are the specific vs. generalized effects of drugs of abuse on neuropsychological performance? Neurosci Biobehav Rev 2011;35(3):377-406

129. Schulte MHJ, Cousijn J, den Uyl TE, Goudriaan AE, van den Brink W, Veltman DJ, et al. Recovery of neurocognitive functions following sustained abstinence after substance dependence and implications for treatment. Clin Psychol Rev 2014;34(7):531-50.

130. Ashare RL, Falcone M, Lerman C. Cognitive function during nicotine withdrawal: Implications for nicotine dependence treatment. Neuropharmacology. 2014;76:581-91.

131. Krall DM, Lim SL, Cooper AM, Burleson PW, Rhoades DJ, Jacquemin SJ, et al. Withdrawal effect of chronic amphetamine exposure during adolescence on complex maze performance. Addict Biol 2014;19(4):634-42.

132. Janetsian SS, Linsenbardt DN, Lapish CC. Memory impairment and alterations in prefrontal cortex gamma band activity following methamphetamine sensitization. Psychopharmacology. 2015;232(12):2083-95.

133. García-Pardo MP, De la Rubia Ortí JE, Calpe MAA. Differential effects of MDMA and cocaine on inhibitory avoidance and object recognition tests in rodents. Neurobiol Learn Mem 2017;146:1-11.

134. Gobin C, Schwendt M. The effects of extended-access cocaine self-administration on working memory performance, reversal learning and incubation of cocaine-seeking in adult male rats. J Addict Prev. 2017;5(1).

135. Berry J, Van Gorp WG, Herzberg DS, Hinkin C, Boone K, Steinman L, et al. Neuropsychological deficits in abstinent cocaine abusers: preliminary findings after two weeks of abstinence. Drug Alcohol Depend 1993;32(3):231-7.

136. Almeida PP, de Araujo Filho GM, Malta SM, Laranjeira RR, Marques ACR, Bressan RA, et al. Attention and memory deficits in crack-cocaine users persist over four weeks of abstinence. J Subst Abus Treat 2017;81:73-8.

137. Potvin S, Stavro K, Rizkallah É, Pelletier J. Cocaine and cognition: a systematic quantitative review. J Addict Med 2014;8(5):368-76.

138. Fein G, Bachman L, Fisher S, Davenport L. Cognitive impairments in abstinent alcoholics. West J Med 1990;152(5):531.

139. Adams KM, Gilman S, Koeppe RA, Kluin KJ, Brunberg JA, Dede $\mathrm{D}$, et al. Neuropsychological deficits are correlated with frontal hypometabolism in positron emission tomography studies of older alcoholic patients. Alcohol Clin Exp Res 1993;17(2):205-10.

140. Oscar-Berman M, Marinković K. Alcohol: effects on neurobehavioral functions and the brain. Neuropsychol Rev 2007;17(3):239-57.

141. Naim-Feil J, Fitzgerald PB, Bradshaw JL, Lubman DI, Sheppard D. Neurocognitive deficits, craving, and abstinence among alcohol-dependent individuals following detoxification. Arch Clin Neuropsychol 2013;29(1):26-37.

142. Calipari ES, Beveridge TJ, Jones SR, Porrino LJ. Withdrawal from extended-access cocaine self-administration results in 
dysregulated functional activity and altered locomotor activity in rats. Eur J Neurosci 2013;38(12):3749-57.

143. Rao KN, Sentir AM, Engleman EA, Bell RL, Hulvershorn LA, Breier A, et al. Toward early estimation and treatment of addiction vulnerability: radial arm maze and $\mathrm{N}$-acetyl cysteine before cocaine sensitization or nicotine self-administration in neonatal ventral hippocampal lesion rats. Psychopharmacology. 2016;233(2324):3933-45.

144. Mandyam CD, Koob GF. The addicted brain craves new neurons: putative role for adult-born progenitors in promoting recovery. Trends Neurosci 2012;35(4):250-60.

145. Cohen A, Soleiman MT, Talia R, Koob GF, George O, Mandyam CD. Extended access nicotine self-administration with periodic deprivation increases immature neurons in the hippocampus. Psychopharmacology. 2015;232(2):453-63.

146. García-Fuster MJ, Parsegian A, Watson SJ, Akil H, Flagel SB. Adolescent cocaine exposure enhances goal-tracking behavior and impairs hippocampal cell genesis selectively in adult bred low-responder rats. Psychopharmacology. 2017;234(8):1293-305.

147. Takashima Y, Mandyam CD. The role of hippocampal adult neurogenesis in methamphetamine addiction. Brain Plasticity 2018;3(2):157-68.

148. Ladrón de Guevara-Miranda D, Millón C, Rosell-Valle C, PérezFernández M, Missiroli M, Serrano A, et al. Long-lasting memory deficits in mice withdrawn from cocaine are concomitant with neuroadaptations in hippocampal basal activity, GABAergic interneurons and adult neurogenesis. Dis Model Mech 2017;10(3): 323-36.

149. Roach MK, Williams RJ. Impaired and inadequate glucose metabolism in the brain as an underlying cause of alcoholism-an hypothesis. Proc Natl Acad Sci U S A 1966;56(2):566-71.

150. Volkow ND, Wang G-J, Kojori ES, Fowler JS, Benveniste H, Tomasi D. Alcohol decreases baseline brain glucose metabolism more in heavy drinkers than controls but has no effect on stimulation-induced metabolic increases. J Neurosci 2015;35(7): 3248-55.

151. Bates ME, Buckman JF, Nguyen TT. A role for cognitive rehabilitation in increasing the effectiveness of treatment for alcohol use disorders. Neuropsychol Rev 2013;23(1):27-47.

152. Volkow ND, Hitzemann R, Wang G-J, Fowler JS, Burr G, Pascani $\mathrm{K}$, et al. Decreased brain metabolism in neurologically intact healthy alcoholics. Am J Psychiatry 1992;149(8):1016-22.

153. Wang GJ, Volkow ND, Franceschi D, Fowler JS, Thanos PK, Scherbaum N, et al. Regional brain metabolism during alcohol intoxication. Alcohol Clin Exp Res 2000;24(6):822-9.

154. Volkow ND, Hitzemann R, Wolf AP, Logan J, Fowler JS, Christman D, et al. Acute effects of ethanol on regional brain glucose metabolism and transport. Psychiatry Res Neuroimaging 1990;35(1):39-48.

155. Wang GJ, Volkow ND, Roque CT, Cestaro VL, Hitzemann RJ, Cantos EL, et al. Functional importance of ventricular enlargement and cortical atrophy in healthy subjects and alcoholics as assessed with PET, MR imaging, and neuropsychologic testing. Radiology. 1993;186(1):59-65.

156. Schreckenberger M, Amberg R, Scheurich A, Lochmann M, Tichy W, Klega A, et al. Acute alcohol effects on neuronal and attentional processing: striatal reward system and inhibitory sensory interactions under acute ethanol challenge. Neuropsychopharmacology : official publication of the American College of Neuropsychopharmacology. 2004;29(8):1527.

157. De Wit H, Metz J, Wagner N, Cooper M. Behavioral and subjective effects of ethanol: Relationship to cerebral metabolism using PET. Alcohol Clin Exp Res 1990;14(3):482-9.

158. Jiang L, Gulanski BI, De Feyter HM, Weinzimer SA, Pittman B, Guidone E, et al. Increased brain uptake and oxidation of acetate in heavy drinkers. J Clin Invest 2013;123(4):1605-14.
159. Dao-Castellana M, Samson Y, Legault F, Martinot J, Aubin H, Crouzel C, et al. Frontal dysfunction in neurologically normal chronic alcoholic subjects: metabolic and neuropsychological findings. Psychol Med 1998;28(5):1039-48.

160. Samson Y, Baron J-C, Feline A, Bories J, Crouzel C. Local cerebral glucose utilisation in chronic alcoholics: a positron tomographic study. J Neurol Neurosurg Psychiatry 1986;49(10):1165-70.

161. Gilman S, Adams K, Koeppe RA, Berent S, Kluin KJ, Modell JG, et al. Cerebellar and frontal hypometabolism in alcoholic cerebellar degeneration studied with positron emission tomography. Ann Neurol 1990;28(6):775-85.

162. Clergue-Duval V, Questel F, Azuar J, Paquet C, Cognat E, Amami $\mathrm{J}$, et al. Brain 18FDG-PET pattern in patients with alcohol-related cognitive impairment. Eur J Nucl Med Mol Imaging 2019.

163. Goldstein RZ, Leskovjan AC, Hoff AL, Hitzemann R, Bashan F, Khalsa SS, et al. Severity of neuropsychological impairment in cocaine and alcohol addiction: association with metabolism in the prefrontal cortex. Neuropsychologia. 2004;42(11):1447-58.

164. Khanna P, Bhat PS, Jacob J. Frontal lobe executive dysfunction and cerebral perfusion study in alcohol dependence syndrome. Ind Psychiatry J 2017;26(2):134.

165. Ritz L, Segobin S, Lannuzel C, Boudehent C, Vabret F, Eustache $\mathrm{F}$, et al. Direct voxel-based comparisons between grey matter shrinkage and glucose hypometabolism in chronic alcoholism. J Cereb Blood Flow Metab 2016;36(9):1625-40.

166. Pitel A-L, Aupée A-M, Chételat G, Mézenge F, Beaunieux H, de la Sayette V, et al. Morphological and glucose metabolism abnormalities in alcoholic Korsakoff's syndrome: group comparisons and individual analyses. PLoS One 2009;4(11):e7748.

167. Wu JC, Buchsbaum MS, Hershey TG, Hazlett E, Sicotte N, Chad Johnson J. PET in generalized anxiety disorder. Biol Psychiatry 1991;29(12):1181-99.

168. Mayberg HS, Brannan SK, Mahurin RK, Jerabek PA, Brickman JS, Tekell JL, et al. Cingulate function in depression: a potential predictor of treatment response. Neuroreport. 1997;8(4):1057-61.

169. Zhao X-H, Wang P-J, Li C-B, Hu Z-H, Xi Q, Wu W-Y, et al. Altered default mode network activity in patient with anxiety disorders: an fMRI study. Eur J Radiol 2007;63(3):373-8.

170. Mergenthaler P, Lindauer U, Dienel GA, Meisel A. Sugar for the brain: the role of glucose in physiological and pathological brain function. Trends Neurosci 2013;36(10):587-97.

171. Watson GS, Craft S. The role of insulin resistance in the pathogenesis of Alzheimer's disease. CNS drugs. 2003;17(1):27-45.

172. Singh BS, Rajakumar PA, Eves EM, Rosner MR, Wainer BH, Devaskar SU. Insulin gene expression in immortalized rat hippocampal and pheochromocytoma-12 cell lines. Regul Pept 1997;69(1):7-14.

173. Stockhorst U, de Fries D, Steingrueber HJ, Scherbaum WA. Insulin and the CNS: effects on food intake, memory, and endocrine parameters and the role of intranasal insulin administration in humans. Physiol Behav 2004;83(1):47-54.

174. Rivera EJ, Goldin A, Fulmer N, Tavares R, Wands JR, de la Monte SM. Insulin and insulin-like growth factor expression and function deteriorate with progression of Alzheimer's disease: link to brain reductions in acetylcholine. J Alzheimers Dis 2005;8(3):247-68.

175. Craft S, Watson GS. Insulin and neurodegenerative disease: shared and specific mechanisms. Lancet Neurol 2004;3(3):169-78.

176. Sandyk R. The relationship between diabetes mellitus and Parkinson's disease. Int J Neurosci 1993;69(1-4):125-30.

177. Petersén $\AA$, Björkqvist M. Hypothalamic-endocrine aspects in Huntington's disease. Eur J Neurosci 2006;24(4):961-7.

178. Guo Z, Chen Y, Mao YF, Zheng T, Jiang Y, Yan Y, et al. Longterm treatment with intranasal insulin ameliorates cognitive impairment, tau hyperphosphorylation, and microglial activation in a streptozotocin-induced Alzheimer's rat model. Sci Rep 2017;7: 45971 . 
179. Marks DR, Tucker K, Cavallin MA, Mast TG, Fadool DA. Awake intranasal insulin delivery modifies protein complexes and alters memory, anxiety, and olfactory behaviors. J Neurosci 2009;29(20):6734-51.

180. Reger MA, Watson GS, Green PS, Wilkinson CW, Baker LD, Cholerton B, et al. Intranasal insulin improves cognition and modulates beta-amyloid in early AD. Neurology. 2008;70(6):440-8.

181. Hamidovic A, Candelaria L, Rodriguez I, Yamada M, Nawarskas J, Burge MR. Learning and memory performance following acute intranasal insulin administration in abstinent smokers. Hum Psychopharmacol 2018;33(2):e2649.

182. Hamidovic A, Khafaja M, Brandon V, Anderson J, Ray G, Allan $\mathrm{AM}$, et al. Reduction of smoking urges with intranasal insulin: a randomized, crossover, placebo-controlled clinical trial. Mol Psychiatry 2017;22(10):1413-21.

183. Hamidovic A. Targeting Mediators of Smoking Persistence with Intranasal Insulin. Front Pharmacol 2017;8:706.

184. Schank JR, Ryabinin AE, Giardino WJ, Ciccocioppo R, Heilig M. Stress-related neuropeptides and addictive behaviors: beyond the usual suspects. Neuron. 2012;76(1):192-208.

185. Plum L, Schubert M, Brüning JC. The role of insulin receptor signaling in the brain. Trends Endocrinol Metab 2005;16(2):59-65.

186. Unger JW, Livingston JN, Moss AM. Insulin receptors in the central nervous system: localization, signalling mechanisms and functional aspects. Prog Neurobiol 1991;36(5):343-62.

187. Chan O, Inouye K, Akirav E, Park E, Riddell MC, Vranic M, et al. Insulin Alone Increases Hypothalamo-Pituitary-Adrenal Activity, and Diabetes Lowers Peak Stress Responses. Endocrinology. 2005;146(3):1382-90.

188. Fruehwald-Schultes B, Kern W, Born J, Fehm HL, Peters A. Hyperinsulinemia causes activation of the hypothalamuspituitary-adrenal axis in humans. Int J Obes 2001;25(1):S38-S40.

189. Fruehwald-Schultes B, Kern W, Bong W, Wellhoener P, Kerner W, Born J, et al. Supraphysiological Hyperinsulinemia Acutely Increases Hypothalamic-Pituitary-Adrenal Secretory Activity in Humans. J Clin Endocrinol Metab 1999;84(9):3041-6.

190. Bohringer A, Schwabe L, Richter S, Schachinger H. Intranasal insulin attenuates the hypothalamic-pituitary-adrenal axis response to psychosocial stress. Psychoneuroendocrinology. 2008;33(10):1394-400.

191. Hallschmid M, Benedict C, Schultes B, Born J, Kern W. Obese men respond to cognitive but not to catabolic brain insulin signaling. Int J Obes 2008;32(2):275-82.

192. Bell ME, Bhatnagar S, Akana SF, Choi S, Dallman MF. Disruption of Arcuate/Paraventricular Nucleus Connections Changes Body Energy Balance and Response to Acute Stress. J Neurosci 2000;20(17):6707-13.

193. Benoit SC, Air EL, Coolen LM, Strauss R, Jackman A, Clegg DJ, et al. The Catabolic Action of Insulin in the Brain Is Mediated by Melanocortins. J Neurosci 2002;22(20):9048-52.

194. Schwartz MW, Sipols AJ, Marks JL, Sanacora G, White JD, Scheurink A, et al. Inhibition of hypothalamic neuropeptide Y gene expression by insulin. Endocrinology. 1992;130(6):3608-16.

195. Sapolsky R, Romero L, Munck A. How do glucocorticois influence stress responses- Integrating permissive, suppressive, stimulatory, and preparative actions. Endocr Rev 2000;21(1):55-89
196. van Praag H, Schinder AF, Christie BR, Toni N, Palmer TD, Gage FH. Functional neurogenesis in the adult hippocampus. Nature. 2002;415(6875):1030-4.

197. Taylor CJ, Jhaveri DJ, Bartlett PF. The therapeutic potential of endogenous hippocampal stem cells for the treatment of neurological disorders. Front Cell Neurosci 2013;7:5.

198. Belujon P, Grace AA. Hippocampus, amygdala and stress: interacting systems that affect susceptibility to addiction. Ann N Y Acad Sci 2011;1216:114.

199. Eisch AJ, Cameron HA, Encinas JM, Meltzer LA, Ming GL, Overstreet-Wadiche LS. Adult neurogenesis, mental health, and mental illness: hope or hype? J Neurosci 2008;28(46):11785-91.

200. Noonan MA, Bulin SE, Fuller DC, Eisch AJ. Reduction of adult hippocampal neurogenesis confers vulnerability in an animal model of cocaine addiction. J Neurosci 2010;30(1):304-15.

201. Castilla-Ortega E, Serrano A, Blanco E, Araos P, Suárez J, Pavon FJ, et al. A place for the hippocampus in the cocaine addiction circuit: Potential roles for adult hippocampal neurogenesis. Neurosci Biobehav Rev 2016;66:15-32.

202. Hoyer S. Glucose metabolism and insulin receptor signal transduction in Alzheimer disease. Eur J Pharmacol 2004;490(1-3): $115-25$.

203. Kleinridders A, Ferris HA, Cai W, Kahn CR. Insulin action in brain regulates systemic metabolism and brain function. Diabetes. 2014;63(7):2232-43.

204. van Dam PS, Aleman A. Insulin-like growth factor-I, cognition and brain aging. Eur J Pharmacol 2004;490(1-3):87-95.

205. Spinelli M, Fusco S, Grassi C. Brain Insulin Resistance and Hippocampal Plasticity: Mechanisms and Biomarkers of Cognitive Decline. Front Neurosci 2019;13:788.

206. van der Heide LP, Kamal A, Artola A, Gispen WH, Ramakers GM. Insulin modulates hippocampal activity-dependent synaptic plasticity in a N-methyl-d-aspartate receptor and phosphatidylinositol-3-kinase-dependent manner. J Neurochem 2005;94(4): 1158-66.

207. Karczewska-Kupczewska M, Tarasów E, Nikołajuk A, Stefanowicz M, Matulewicz N, Otziomek E, et al. The effect of insulin infusion on the metabolites in cerebral tissues assessed with proton magnetic resonance spectroscopy in young healthy subjects with high and low insulin sensitivity. Diabetes Care 2013;36(9):2787-93.

208. Guthoff M, Grichisch Y, Canova C, Tschritter O, Veit R, Hallschmid M, et al. Insulin Modulates Food-Related Activity in the Central Nervous System. J Clin Endocrinol Metab 2009.

209. Jauch-Chara K, Friedrich A, Rezmer M, Melchert UH, H GS-E, Hallschmid M, et al. Intranasal insulin suppresses food intake via enhancement of brain energy levels in humans. Diabetes. 2012;61(9):2261-8.

210. Moreno-López L, Stamatakis EA, Fernández-Serrano MJ, Gómez-Río M, Rodríguez-Fernández A, Pérez-García M, et al. Neural correlates of the severity of cocaine, heroin, alcohol, MDMA and cannabis use in polysubstance abusers: a restingPET brain metabolism study. PLoS One 2012;7(6):e39830.

Publisher's Note Springer Nature remains neutral with regard to jurisdictional claims in published maps and institutional affiliations. 